\title{
Predicting freshwater habitat integrity using land-use surrogates
}

\author{
MA Amis ${ }^{1,2 *}$, M Rouget ${ }^{2,3}$, A Balmford ${ }^{1,4}$, W Thuiller $^{5}, \mathrm{CJ}$ Kleynhans $^{6}$, J Day and J Nel ${ }^{8}$ \\ ${ }^{1}$ Percy FitzPatrick Institute, University of Cape Town, Rondebosch 7701, South Africa \\ ${ }^{2}$ Conservation Planning Unit, Kirstenbosch Research Centre, South African National Biodiversity Institute, Private Bag X7, \\ Claremont, Cape Town 7735, South Africa \\ ${ }^{3}$ Department of Botany, University of Cape Town, Rondebosch 7701, South Africa \\ ${ }^{4}$ Conservation Biology Group, Department of Zoology, University of Cambridge, CB2 3EJ, UK \\ ${ }^{5}$ Laboratoire d'Ecologie Alpine, CNRS. Université Joseph Fourier. BP 53, 38041 Grenoble Cedex 9, France \\ ${ }^{6}$ Resource Quality Services, Department of Water Affairs and Forestry, Private Bag, X313, Pretoria, South Africa \\ ${ }^{7}$ Department of Zoology, University of Cape Town, Rondebosch 7701, South Africa \\ ${ }^{8}$ CSIR-Environmentek, PO Box 320, Stellenbosch 7599, South Africa
}

\begin{abstract}
Freshwater biodiversity is globally threatened due to human disturbances, but freshwater ecosystems have been accorded less protection than their terrestrial and marine counterparts. Few criteria exist for assessing the habitat integrity of rivers and data used for such assessments are generally of limited geographical coverage. Here, we use a fine-scale dataset describing river integrity in north-western South Africa to explore the extent to which measures of freshwater habitat integrity can be predicted from remotely sensed data, which are readily available in many parts of the world. A spatial statistical model was built using broad land-cover variables to predict the habitat integrity (subdivided into riparian and instream integrity) of rivers. We also explored the importance of the spatial scale. Results showed that riparian and, to a lesser degree, instream habitat integrity of river systems could be predicted with reasonable accuracy. The total area under natural vegetation was the most significant predictor of riparian integrity, which is best predicted by land-use activities at catchment level, rather than more locally. Our GIS-based model thus provides a fine-scale approach to assessing river habitat integrity as a supplement to landscape-level conservation plans for river systems, and represents a significant contribution towards the monitoring component of the River Health Programme (RHP), which reports on the state of rivers in South Africa.
\end{abstract}

Keywords: freshwater habitat integrity, land use, GIS, conservation planning, predictive modelling

\section{Introduction}

The conservation status of freshwater ecosystems worldwide is poor and declining fast, with rivers and wetlands among the most threatened of all ecosystems (Vitousek et al., 1997, Revenga et al., 2000) as a result of severe alteration by human activity (Moyle and Williams, 1990; Jensen et al., 1993). Although a comprehensive global assessment of the status of freshwater biodiversity is difficult to carry out (Revenga et al., 2000), the few estimates that exist are cause for serious concern. About $30 \%$ of freshwater vertebrate species in the world have become extinct, threatened or endangered (World Conservation Union, 2000). The situation is even more serious for other freshwater faunal groups (Abell, 2002). The challenge to conservation biologists is to acknowledge the freshwater biodiversity crisis, and to focus research on topical issues. Current research does not seem to reflect adequate concern for this crisis (Abell, 2002).

Despite their obvious importance and the seriousness of the threats they face, freshwater ecosystems remain poorly understood and inadequately represented in biodiversity assessments (Higgins, 2003). One reason for the disparity between freshwater and terrestrial conservation planning is the lack of techniques for rapid assessment of the ecological/ habitat integrity of fresh-

\footnotetext{
* To whom all correspondence should be addressed.

正 +2721 797 6903; fax: +27 21799 8738;

e-mail: amis@sanbi.org

Received 24 March 2006; accepted in revised form 28 November 2006.
}

water ecosystems. Such assessments are resource intensive, so there is a dearth of information on many freshwater ecosystems and those data that are available for conservation planning are often inadequate for fine-scale planning.

Definitions of river health and ecological integrity, and methods for their assessment, are still a subject of considerable debate (Wicklum and Davies, 1995; Norris and Norris, 1995; Norris and Thoms, 1999; Quigley et al., 2001). Ecological integrity may be defined as 'the ability to support and maintain a balanced, integrated, adaptive community of organisms having a species composition, diversity, and functional organization comparable to that of natural habitat of the region' (Angermeier and Karr, 1994). However, these terms are used loosely in this study as its main focus is on the physical/habitat integrity of the river systems.

In South Africa, the status of freshwater ecosystems matches trends worldwide, recent assessments showing that $44 \%$ of the main stems of South Africa's rivers are critically endangered; main stems here refer to rivers of order 4 and above ( $\mathrm{Nel}$ et al., 2004. These statistics reflect the dire need to incorporate freshwater ecosystems into the mainstream conservation planning process. Assessment of freshwater ecosystems has focused todate on the main stem of rivers leaving out tributaries (e.g. the National Spatial Biodiversity Assessment, Nel et al., 2004), even though most of these have been greatly transformed by human impacts. With the main stem of some of the rivers already seriously damaged, conservation attention could usefully focus on tributaries, although data on most of these is extremely limited for conservation planning. 
Fortunately for South Africa, relatively good geographical information systems (GIS) data are available on terrestrial biodiversity and land cover. Recent terrestrial conservation plans developed in South Africa, which use these data for systematic planning are probably the most detailed and explicit for any part of the developing world (Balmford, 2003). The availability of this information presents an opportunity for freshwater systems too: if available fine-scale information on the ecological integrity of rivers can be predicted with reasonable confidence using remotely-sensed data, then in principle GIS data could be used to estimate freshwater integrity more widely, thus accelerating freshwater conservation planning. The development of techniques that use broad surrogates for assessing the habitat/ ecological integrity of freshwater ecosystems is critical for conservation planning.

The overall aim of the present study was to use available data on South African rivers to test the feasibility of GIS-based assessment of the ecological/habitat integrity of rivers. Specifically, the objectives were to:

- Develop a GIS-based model for predicting river habitat integrity

- Establish the spatial scale at which GIS data best predict habitat integrity.

\section{Methods}

\section{Study area}

The Crocodile (West) and Marico Water Management Area (WMA) (Fig. 1) is one of 19 WMAs in South Africa. It covers an area of $4.7 \mathrm{~m}$. ha, forms part of the Limpopo River basin (which spans four countries - Botswana, Zimbabwe, South Africa and Mozambique), and includes South Africa's economic centre (e.g. Johannesburg and Pretoria). The climate of the area is semi-arid, so water demand is considerable, irrigation accounting for $37 \%$ and the rest being attributable to urban, industrial and mining needs (DWAF, 2004). Agriculture is the most extensive land use, accounting for $53 \%$ of the area; other major economic activities include mining and light industries (DWAF, 2002b).

For the purposes of this study, the area was divided into 25 regions (hereafter referred to as 'catchments') (Fig. 1), which vary widely in area, average stream length, and stream order
(Table 1). The delineation was based on 'Level 2' ecoregions (Roux, 1999). Level 1 ecoregions were delineated on the basis of physiography, climate, geology, soils and potential natural vegetation (DWAF, 1999; Roux et al., 2002; Kleynhans et al., 2005). The areas under Level 2 ecoregions are a refinement of Level 1 ecoregions and are based on variations in geology, natural vegetation and altitude, as well as expert knowledge of the rivers that flow through the planning domain (Kleynhans et al., 2005).

\begin{tabular}{|c|c|c|c|c|}
\hline \multicolumn{5}{|c|}{$\begin{array}{c}\text { TABLE 1 } \\
\text { Characteristics of the 22 catchments assessed } \\
\text { using the land use predictor models }\end{array}$} \\
\hline $\begin{array}{c}\text { Catch- } \\
\text { ments }\end{array}$ & $\begin{array}{c}\text { No. of } \\
\text { monitor- } \\
\text { ing sites }\end{array}$ & $\begin{array}{c}\text { Area of } \\
\text { catch- } \\
\text { ments } \\
\text { (km }^{2}\end{array}$ & $\begin{array}{c}\text { Range of } \\
\text { stream- } \\
\text { lengths } \\
\text { (km) }\end{array}$ & $\begin{array}{c}\text { Stream order } \\
\text { (perennial or } \\
\text { non-perennial) }\end{array}$ \\
\hline E1 & 12 & 1763.74 & $10.0-25.0$ & P\& N \\
\hline E2 & 4 & 731.65 & 62.9 & P \\
\hline E3 & 8 & 1204.02 & $9-39.7$ & P\& N \\
\hline E4 & 8 & 2105.30 & $9.2-49.5$ & P\& N \\
\hline E5 & 4 & 1313.28 & $14.5-49.5$ & P \\
\hline E6 & 3 & 544.48 & $18.1-27.2$ & P \\
\hline E7 & 9 & 775.11 & 62.7 & $\mathrm{~N}$ \\
\hline E8 & 5 & 619.29 & $14.9-31.8$ & $\mathrm{~N}$ \\
\hline E9 & 3 & 328.64 & 16.2 & $\mathrm{~N}$ \\
\hline E10 & 2 & 413.90 & 31.2 & $\mathrm{~N}$ \\
\hline E11 & 8 & 1217.66 & $12.0-43.3$ & $\mathrm{P}$ \\
\hline E12 & 4 & 1556.29 & $7.7-22.0$ & $\mathrm{P}$ \\
\hline E13 & 5 & 4173.10 & $7.6-43.3$ & $\mathrm{P}$ \\
\hline E14 & 1 & 1215.32 & 48.1 & $\mathrm{P}$ \\
\hline E15 & 7 & 968.15 & $31.7-60.5$ & $\mathrm{P}$ \\
\hline E16 & 5 & 2113.39 & $1.0-23.2$ & $\mathrm{P}$ \\
\hline E17 & 5 & 1571.16 & $9.6-47.0$ & $\mathrm{P}$ \\
\hline E18 & 8 & 980.42 & $8.4-46.0$ & $\mathrm{P}$ \\
\hline E19 & 7 & 1167.99 & $5.4-71.8$ & P\& N \\
\hline E20 & 6 & 1904.27 & $42.1-57.2$ & $\mathrm{P}$ \\
\hline E21 & 3 & 2714.35 & $19.7-35.1$ & $\mathrm{P}$ \\
\hline E22 & 6 & 1781.51 & $20.9-28.1$ & $\mathrm{P}$ \\
\hline & & & & \\
\hline
\end{tabular}

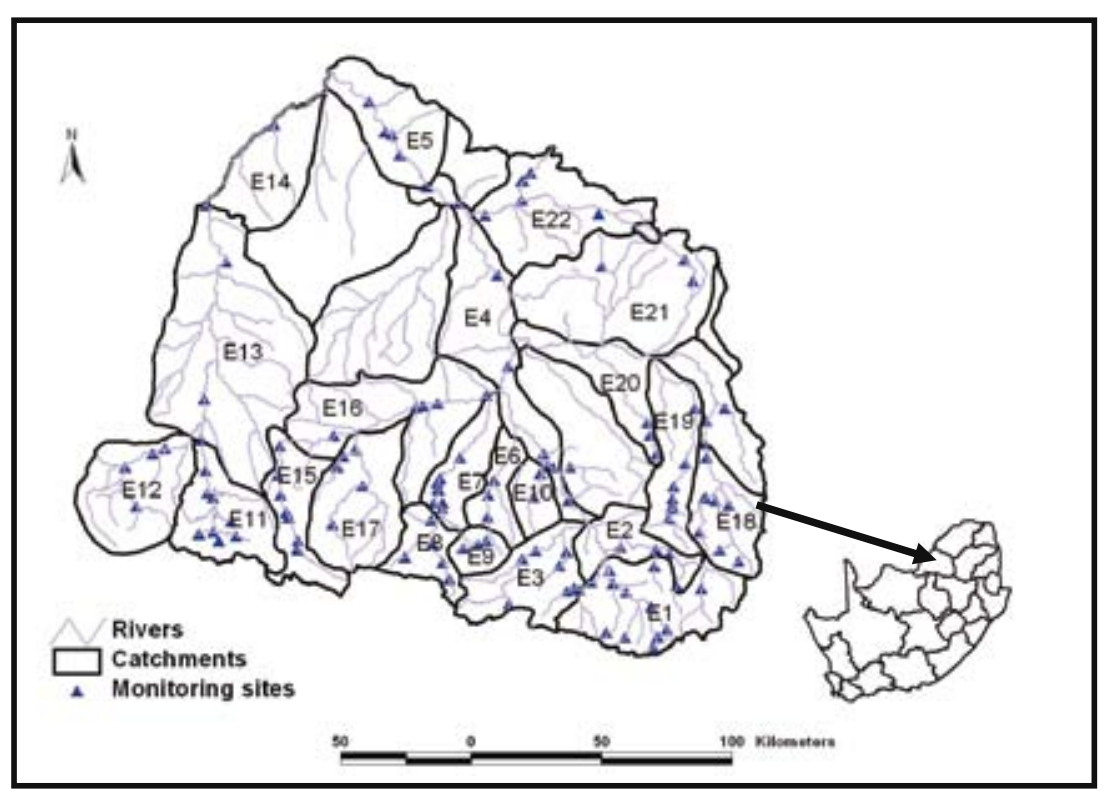

Figure 1

Monitoring sites for the assessment of instream biotic response used for the development of the fish assemblage integrity index (FAll), major river systems, and the delineations of the ecological study units in the Crocodile (West) and Marico Water Management Area. 


\section{Ecological integrity of the river systems}

Data on the habitat/ecological integrity of the river systems in the study area were obtained from a previous study carried out for River Health Programme (RHP) as part of the state-of-rivers report (RHP, 2005). The RHP is a national biomonitoring programme whose mandate is to assess and monitor the habitat/ecological integrity of riverine ecosystems in South Africa (Roux et al., 1999). Ecological integrity of the river systems was assessed on the basis of the response of biota and the physical habitat integrity of the river systems from a set of reference conditions. Two indices were used to assess ecological integrity namely, the index of habitat integrity (IHI), for assessing physical habitat integrity (Kleynhans, 1996), and the Fish Assemblage Integrity Index (FAII) for assessing biotic integrity (Kleynhans, 1999). The lists of proxy variables used to build these indices are listed in Table 2.

Weights were assigned to each parameter by experts for their relative impact on habitat integrity, based on the experts' experience and on the literature. Each parameter was then assessed through field observations either at specific monitoring sites (Fig. 1) or at the scale of catchments depending on the parameter. Following the field observations and assessments, a score (maximum value $=25$ ) was assigned for each parameter, and the impact of the parameter on habitat integrity was calculated thus:

$$
\begin{aligned}
& \text { Impact of parameter on habitat integrity } \\
& =\frac{\text { Rating for the parameter }}{\text { Maximum value (25) }} \times \frac{\text { Weight (percentage) }}{1}
\end{aligned}
$$

The impact of all the individual parameters were then summed up and expressed as a percentage and subtracted from 100 to arrive at an independent value of habitat integrity, which was also the value for riparian integrity. While instream ecological integrity was calculated as the average of instream habitat integrity derived in the above procedure and the biotic integrity derived using the Fish Assemblage Integrity Index (FAII). FAII measures the biotic integrity of river systems based on attributes of native fish (with the presence of alien fish reducing the score). The index is based on the relative intolerance of fish occurring in a given river segment, and four components were taken into consideration in estimating intolerance namely, habitat preferences and specialization, food preference and specialization, requirements for flowing water during different life stages and association with habitats with unmodified water quality. Refer to (Kleynhans, 1999) for a description of how the instream biotic integrity index was developed and its application. Assessments of fish biota were carried out at site-specific monitoring sites indicated in Fig. 1.

For reporting purposes, scores of river integrity (instream and riparian) were categorised by the RHP into the following bands: $-\mathrm{A}=(100) ; \mathrm{B}=(80-99) ; \mathrm{C}=(60-79) ; \mathrm{D}=(40-59) ; \mathrm{E}=$ (20-39); F = (0-19), (Kleynhans, 1996). Category (A) represents a natural unmodified river system, while category $(\mathrm{F})$ represents a very highly modified system with almost a complete loss of natural habitat.

\section{Quantification of potential surrogates of freshwater habitat integrity}

We chose a series of land-use variables that might be suitable

\begin{tabular}{|c|c|c|c|c|}
\hline \multicolumn{5}{|c|}{$\begin{array}{l}\text { TABLE } 2 \\
\text { Parameters used to build the riparian and instream } \\
\text { habitat integrity indices (Klynhans 1996) and their } \\
\text { respective weights in the River Health Program of } \\
\text { South Africa }\end{array}$} \\
\hline Parameters & \begin{tabular}{|l|} 
Riparian \\
Integrity \\
\end{tabular} & Weights & \begin{tabular}{|l|} 
Instream \\
Integrity \\
\end{tabular} & Weights \\
\hline Fish assemblage & $\mathrm{N} / \mathrm{A}$ & & $\sqrt{ }$ & \\
\hline Exotic Macrophytes & N/A & & $\sqrt{ }$ & 9 \\
\hline Exotic fauna & N/A & & $\sqrt{ }$ & 8 \\
\hline Vegetation decrease & $\sqrt{ }$ & 13 & $\mathrm{~N} / \mathrm{A}$ & \\
\hline Exotic vegetation & $\sqrt{ }$ & 12 & N/A & \\
\hline Bank erosion & $\sqrt{ }$ & 14 & $\mathrm{~N} / \mathrm{A}$ & \\
\hline Channel modification & $\sqrt{ }$ & 12 & $\sqrt{ }$ & 13 \\
\hline Water abstraction & $\sqrt{ }$ & 13 & $\sqrt{ }$ & 14 \\
\hline Inundation & $\sqrt{ }$ & 11 & $\sqrt{ }$ & 10 \\
\hline Flow modification & $\sqrt{ }$ & 12 & $\sqrt{ }$ & 13 \\
\hline Water quality & $\sqrt{ }$ & 13 & $\sqrt{ }$ & 14 \\
\hline Bed modification & $\mathrm{N} / \mathrm{A}$ & & $\sqrt{ }$ & 13 \\
\hline Solid Waste & N/A & & $\sqrt{ }$ & 6 \\
\hline
\end{tabular}
predictors for assessing freshwater habitat integrity from the

\begin{tabular}{|l|l|}
\hline $\begin{array}{l}\text { Variables used as potential predictors of river integ- } \\
\text { rity, and a description of the measures used in their } \\
\text { quantification. All variables were derived from the } \\
\text { land cover map, with the exception of population, } \\
\text { number of mines, roads and dams that were derived } \\
\text { from a separate GIS layer. }\end{array}$ \\
\hline Predictors & Description \\
\hline Natural vegetation & Area under natural vegetation cover $(\%)$ \\
\hline Plantations & $\begin{array}{l}\text { Area under forest \& grassland planta- } \\
\text { tions (\%) }\end{array}$ \\
\hline Degraded areas & $\begin{array}{l}\text { Area under man-induced low vegetation } \\
\text { cover }(\%)\end{array}$ \\
\hline Cultivated areas & Area under all forms of agriculture (\%) \\
\hline $\begin{array}{l}\text { Rural clusters } \\
\text { (dwellings) }\end{array}$ & $\begin{array}{l}\text { Area under clustered rural dwellings } \\
(\%)\end{array}$ \\
\hline $\begin{array}{l}\text { Residential/com- } \\
\text { mercial areas }\end{array}$ & $\begin{array}{l}\text { Area under residential or commercial } \\
\text { usage }(\%)\end{array}$ \\
\hline Industrial & Built up industrial area (\%) \\
\hline Mines & Area used for mining (\%) \\
\hline Eroded areas & $\begin{array}{l}\text { Area under bare rock/soil (gully or sheet } \\
\text { erosion) }(\%)\end{array}$ \\
\hline Roads & Length of roads (km / km²) \\
\hline Dams & Area under dams (\%) \\
\hline Population* & Population density (people / km²) \\
\hline Number of mines & Total number of active mines \\
\hline Area & $\begin{array}{l}\text { Total area of catchments/planning unit } \\
\text { (ha) }\end{array}$ \\
\hline
\end{tabular}

* Assessed only at the scale of catchments

land cover map (CSIR 2005) and added separate GIS surfaces for human population density and the distribution of mines. A total of 14 variables, including the total area of each catchment were assessed for their ability to predict freshwater habitat integrity (Table 3 ). The land-use variables were derived by reclassifying the initial 49 land-use types from the land-cover map. 
For instance, we lumped all natural vegetation types together to form a single land-use type. Since the study was on water bodies they were excluded from the list of land-use variables used as predictors. This reclassification was necessary so as to avoid too many independent variables for subsequent modelling.

Because river integrity may be influenced not only by local conditions but also by more distant patterns of land use (e.g Allan et al., 1997), we attempted to predict river integrity scores using land-use data compiled across a range of distances from the river in question. Riparian strips were 'created' on both sides of the river, and along its entire length in the catchment, to capture land use up to $100 \mathrm{~m}, 500 \mathrm{~m}, 1000 \mathrm{~m}, 2000 \mathrm{~m}$ and $3000 \mathrm{~m}$ from the river of interest, using Arcview 3.2a and ArcInfo (ESRI, Redlands, CA). This choice of strip sizes was arbitrary. Land-use variables (e.g. the extent of natural vegetation) were summarised within each riparian strip. We also compiled catchment-wide summaries of land use, so that together with the riparian strips, analyses were carried out at six spatial scales $(100 \mathrm{~m}, 500 \mathrm{~m}, 1000 \mathrm{~m}, 2000 \mathrm{~m}, 3000 \mathrm{~m}$ and entire catchment).

\section{The model}

We derived models predicting river habitat integrity using data on 22 of the 25 catchments because insufficient data were available for the other three. We chose to use generalized linear models (GLMs; Chambers and Hastie, 1992) to predict integrity scores because we were looking for simple relationships and also because, given our small sample of catchments, we wanted to avoid over-fitting our models and thereby limiting their broader applicability (Vanderpoorten et al., 2005). With more data, generalized additive models could have been more suitable. We assessed the potential surrogates of riparian and instream integrity independently of each other, using riparian and the instream integrity scores as dependent variables in a series of GLMs.

\section{Fitting the model}

We built six GLMs, one for each of the different spatial scales, in S-Plus software (Mathsoft, 1999) using GLM with Poisson error distribution (link function $=\log (m \mu)$, variance $=m \mu$ ), because we were using non-negative variables (Crawley, 1993). Due to limited sample sizes we constrained the models in various ways. No attempt was made to mix the spatial scales at which pre-

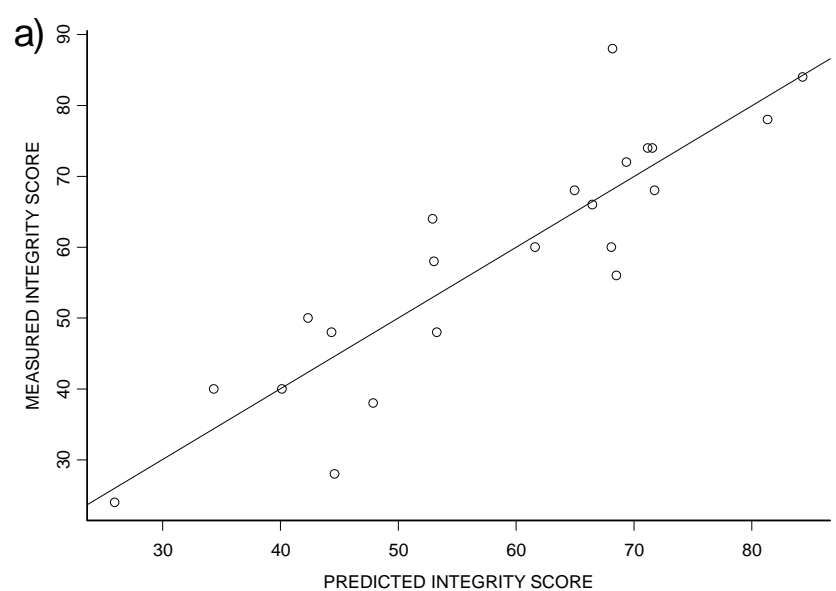

dictor variables were measured within a given model (i.e. the same model did not include land-use variables derived from, for instance, both $100 \mathrm{~m}$ and $500 \mathrm{~m}$ riparian strips). We also did not consider any possible interactions between the various predictor variables, even though it is possible that the magnitude of the effect of one variable on river integrity may depend on the effect of other variables (Chambers and Hastie, 1999). Interactions could result in over-fitting the model, and they are difficult to interpret.

In all instances where the model output contained several predictors, we limited the number to the four best explanatory variables; based on Akaike Information Criterion (AIC) scores (Akaike, 1974). The maximum number of parameters used in the model was limited to four due to the small sample size, and to facilitate the comparison between competing explanatory models compiled at different spatial scales.

\section{Testing the accuracy of the models}

To quantify the predictive power of each model, $r^{2}$ values were calculated. We also assessed how the catchments' integrity categories (A to F) predicted by each model compared to those assigned by the River Health Programme using the index of habitat integrity (Kleynhans, 1996).

\section{Results}

\section{Overall predictive power of the models}

Modelling riparian and instream integrity in the 22 catchments of the study area revealed that riparian integrity (Fig. 2a; Table 4) could be predicted more accurately than instream integrity (Fig. 2b; Table 5). Both aspects of integrity were better predicted by land use measured over the entire catchment (for riparian: $\mathrm{r}^{2}$ $=0.79$; for instream: $\mathrm{r}^{2}=0.68$ ) than along riparian strips (e.g. $100 \mathrm{~m}$ for both riparian and instream integrity: $\mathrm{r}^{2}=0.5$ ) (Tables 4 and 5).

\section{Most important variables for predicting river integrity}

The relative extent of cover by natural vegetation was the single most powerful land-use variable for predicting riparian integrity scores, with positive correlations emerging in all analysis (Table 4). Another important and independent predictor was

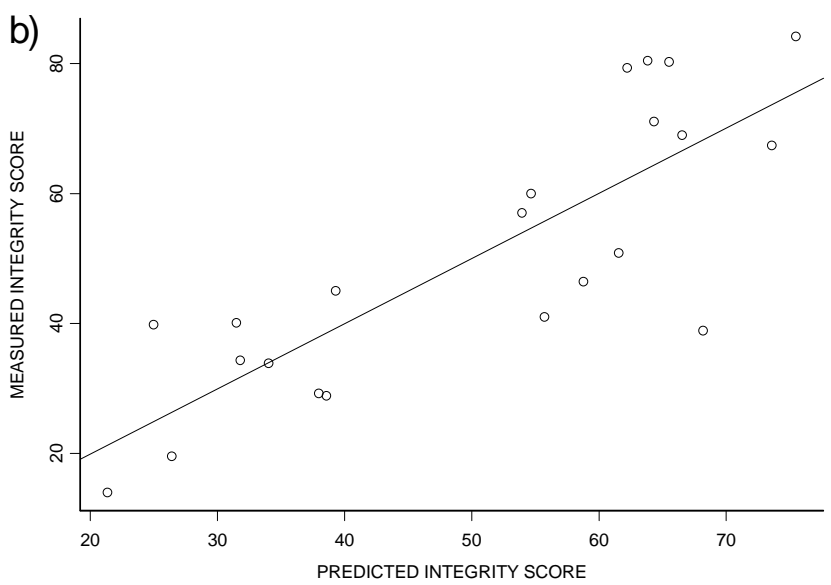

Figure 2

Accuracy of a) predicted riparian integrity based on the model at the scale of catchments $\left(r^{2}=0.79\right)$

b) Predicted instream integrity based on the model at the scale of catchments $\left(r^{2}=0.68\right)$. 


\begin{tabular}{|c|c|c|c|c|c|c|c|c|c|}
\hline $\begin{array}{l}\text { Output of the six } \\
\text { fect of land use vo } \\
\text { the strength of pr } \\
\text { signify the effec } \\
\text { according to the } \\
\text { vegetation ( }+ \text { res } \\
\text { variables shown } \\
\text { nificant at } p<0.0 \\
\text { examined, but did } \\
\text { tors at any scale: } \\
\text { of industrial area, } \\
\text { total a }\end{array}$ & $\begin{array}{l}\text { TA } \\
\text { ffer } \\
\text { iabl } \\
\text { dicti } \\
\text { of th } \\
\text { nod } \\
\text { Ilts } \\
\text { the } \\
\text {. Th } \\
\text { ot } f \\
\text { Culti } \\
\text { ens }\end{array}$ & $\begin{array}{l}\text { BL } \\
\text { ent } \\
\text { es } \\
\text { on } \\
\text { he } p \\
\text { el (e } \\
\text { in } h\end{array}$ & $\begin{array}{l}\text { E } 4 \\
\text { mo } \\
\text { on } \\
\left(r^{2}\right) \\
\text { par } \\
\text { e.g. } \\
\text { igh } \\
\text { fer } \\
\text { ollo } \\
\text { ure } \\
\text { ted } \\
\text { of }\end{array}$ & atcn & n & ent & $\begin{array}{l}\text { win } \\
\text { nteg } \\
\text { and } \\
\text { n int } \\
\text { in } \\
\text { ity). } \\
\text { Is w } \\
\text { iabl } \\
\text { tan } \\
\text { lation }\end{array}$ & $\begin{array}{l}\text { ig th } \\
\text { grity } \\
(-) \mathrm{s} \\
\text { tegr } \\
\text { natu } \\
\text {. All } \\
\text { vere }\end{array}$ & $\begin{array}{l}\text { e e } \\
\text { y an } \\
\text { sign } \\
\text { rity } \\
\text { ural } \\
\text { the } \\
\text { sig } \\
\text { wer } \\
\text { edic } \\
\text { ove } \\
\text { n an }\end{array}$ \\
\hline Riparian & 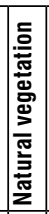 & 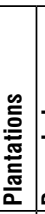 & 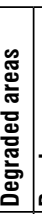 & & & & & 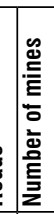 & 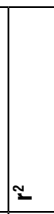 \\
\hline $100 \mathrm{~m}$ riparian strip & + & - & & & + & & + & & 0.5 \\
\hline $500 \mathrm{~m}$ riparian strip & + & & - & + & & & & - & 0.7 \\
\hline $1000 \mathrm{~m}$ riparian strip & + & & - & + & & & & - & 0.6 \\
\hline 2000 m riparian strip & + & & - & + & & & & - & 0.7 \\
\hline $3000 \mathrm{~m}$ riparian strip & + & & & & & + & + & - & 0.7 \\
\hline Catchments & + & & & & & +- & + & - & 0.7 \\
\hline
\end{tabular}

the number of mines in the vicinity of the catchment. With the exception of the model based on riparian strip nearest the river $(100 \mathrm{~m})$, all models featured the number of mines as a significant negative predictor of riparian integrity. Interestingly, the number of mines appears to be more important than the relative area occupied by mining activities. Other land-use variables that predict riparian integrity, but only at specific spatial scales, included the relative extent of degraded areas, areas occupied by mines, areas supporting rural dwellings, and eroded areas (Table 4). Rather surprisingly, the density of roads, the proportions of area under cultivation and plantation, and the relative extent of dams, industry, eroded areas, and built-up residential or commercial areas were not important predictors of riparian integrity, although this might be related to the scale of the assessment (Table 4).

The most significant predictors for instream integrity were not very different from those for riparian integrity. For all but

\section{TABLE 5}

Output of the six different models showing the effect of land use variables on instream integrity, and the strength of prediction $\left(r^{2}\right)$. The $(+)$ and $(-)$ signs signify the effect of the parameter on integrity according to the model (e.g. increase in natural vegetation (+) results in higher integrity). All the variables included in the different models were significant at $p<0.001$. The following variables were examined, but did not feature as important predictors at any scale: cultivated areas, and the total area of the catchment.

\begin{tabular}{|c|c|c|c|c|c|c|c|c|c|c|c|c|c|}
\hline Instream & 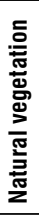 & 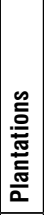 & 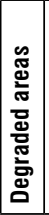 & 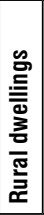 & 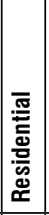 & 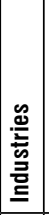 & 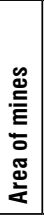 & 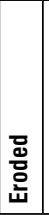 & 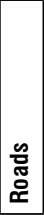 & 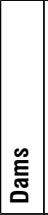 & $\begin{array}{l}\text { 흘 } \\
\text { 흘 } \\
\text { 흥 }\end{array}$ & 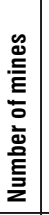 & $\simeq$ \\
\hline 100 m riparian strip & & - & - & - & - & & & & & & & & 0.5 \\
\hline 500 m riparian strip & + & - & - & & & & & & & & & & 0.47 \\
\hline 1000 m riparian strip & & & & & - & + & & & & & & & 0.52 \\
\hline 2000 m riparian strip & + & - & & - & & + & & & & & & & 0.64 \\
\hline 3000 m riparian strip & + & - & & - & & + & & & & & & & 0.64 \\
\hline Catchments & + & & & & & & - & & & + & - & & 0.68 \\
\hline
\end{tabular}

the $100 \mathrm{~m}$ and $1000 \mathrm{~m}$ buffer analysis, cover by natural vegetation was again the key determinant of instream integrity (Table 5). The relative extents of plantations, of rural dwellings, and of industrial (industries) developments were also found to be significant predictors of instream integrity at most scales, while the relative area of mines, population density and the density of dams were important only at larger scales (Table 5). The relative extent of cultivated lands, road density, and the total area of the catchment did not feature as significant predictors of instream integrity (Table 5).

\section{Model application for state of the rivers (SOR) reporting}

Modelled integrity values generally fall into the same category of ecological integrity as those provided in the River Health Programme report, riparian integrity having an accuracy of $77 \%$, relative to measured RHP scores. Incorrect predictions are either overestimated or underestimated mostly by only a single class (Fig. 3). The accuracy of prediction of the appropriate cat-
Figure 3

Predictions of riparian Integrity using different spatial scales $(\boldsymbol{a}=100 \mathrm{~m}, \boldsymbol{b}=500 \mathrm{~m}, \boldsymbol{c}=$ $1000 \mathrm{~m}, \boldsymbol{d}=2000 \mathrm{~m}, \boldsymbol{e}=$ $3000 \mathrm{~m}, \boldsymbol{f}=$ entire catchment). The map outside the box depicts measured integrity. The signs show whether the model has over estimated $(+)$ or underestimated (-) riparian integrity, based on measured integrity.

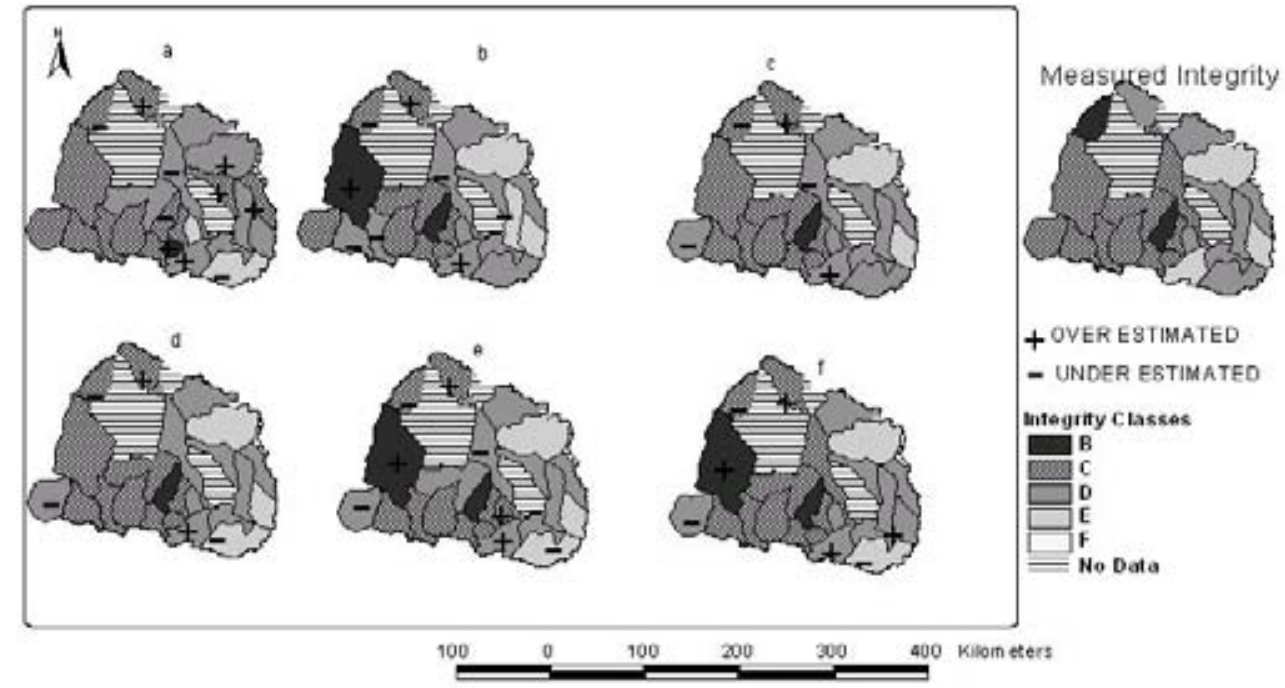


egory for instream integrity was much lower than for riparian integrity, with a score of $58 \%$. Accuracy was calculated as the percentage of those catchments whose predicted integrity score falls in the same category as the measured integrity (Fig. 3).

\section{Discussion}

The analyses suggest that both riparian and, to a lesser extent instream integrity can be predicted with reasonable accuracy using a series of widely available variables representing land use, settlement, and infrastructure. Riparian integrity was predicted more accurately than instream integrity, probably because riparian integrity is primarily a reflection of physical characteristics such as bank condition and the extent and type of vegetation cover of the riparian zone and also of adjacent land. In contrast, land-use data are relatively poor predictors of instream integrity, which in large part is linked to the structure of the biotic community of the river, itself only indirectly impacted by adjacent land use.

Natural vegetation cover was the most important predictor of both riparian and instream integrity. This was not surprising because natural vegetation may regulate stream processes like erosion (Berkman and Rabeni, 1987) and sediment transport (Osborne and Kovacic, 1993), and thus channel morphology (Naiman et al., 1993). In the absence of other data on the state of a river, assessing the natural vegetation cover alone can provide a fairly reasonable prediction of integrity. Such assessments are very useful for purposes of prioritising river systems for conservation interventions and for monitoring progress towards achieving the millennium development goals. Other potential predictors like density of the road network, and the relative coverage of dams, industries, eroded areas and cultivated lands, did not predict river integrity. Poor correlations between these measures and the ecological integrity indices used in this study suggest that they are not necessarily the best broad surrogates for predicting river integrity, even though they are widely recognised (e.g. Roth et al., 1996; Quigley et al., 2001; Higgins, 2003) as major modifiers of rivers.

The influence of land use on river integrity is known to be scale-dependent (e.g. Allan et al., 1997; Sponseller et al., 2001; Morely and Karr, 2002), and this was found to be the case here, in that land use at the catchment level provided the best prediction of overall river integrity. Instream processes, such as the input of organic matter, may depend on local vegetation cover, while nutrient supply, channel characteristics and hydrology are influenced by activities at the catchment scale. The fact that some potential predictors were useful in predicting integrity only at specific spatial scales may imply that the scale of analyses also affects individual predictors.

It would be useful to validate the models developed in this study using a larger sample of field-based data, spanning a broad range of ecological and land-use conditions. The field-based data could then be divided into suitably-sized calibration and validation datasets, to test the robustness of this approach. However, at present the models have not been validated against such an independent dataset, because the sample sizes were not large enough, which could have made the validation of the models difficult (Stockwell and Peterson, 2002).

It should be emphasised that predictive modelling cannot replace field-based surveys, (Roth et al., 1996). However, with advances in GIS technology and increasing focus on landscapescale conservation planning, predictive modelling may play a vital role in bridging the gap when planning for the conservation of both terrestrial and aquatic ecosystems.

\section{Acknowledgements}

The South African National Biodiversity Institute (SANBI), the CSIR), and the Tropical Biology Association (TBA) funded the project. We are grateful to the Percy FitzPatrick Institute, Zoology Department, University of Cape Town and many individuals who contributed significantly towards this project.

\section{References}

ABELL R, THIEME M, DINERSTEIN E and OLSON D (2002) A Sourcebook for Conducting Biological Assessments and Developing Biodiversity Visions for Ecoregion Conservation. Volume II: Freshwater Ecoregions. World Wildlife Fund, Washington, D.C. USA.

ABELL R (2002) Conservation biology for the biodiversity crisis: a freshwater follow up. Conserv. Biol. 16 (5) 1435-1437.

AKAIKE H (1974) A new look at statistical model identification. IEEE transactions on automatic control. AU-19 716-722.

ALLAN JD, ERICKSON DL and FAY J (1997) The influence of catchment land use on stream integrity across multiple scales. Freshwater Biol. 37149-161.

ANGERMEIER PL and KARR JR (1994) Biological integrity versus biological diversity as policy directives. Biosci. 44 690-697.

BALMFORD A (2003) Conservation planning in the real world: South Africa shows the way. Trends Ecol. Evol. 18 (9) 435-438.

BERKMAN GC and RABENI CF (1987) Effect of siltation on stream fish communities. Environ. Biol. Fish. 18 285-294.

BOULTON AJ (1999) An Overview of river health assessment: Philosophies, practice, problems and prognosis. Freshwater Biol. 41 469- 479.

CHAMBERS JM and HASTIE TJ (1992) Statistical Models in S. Wadsworth \& Brooks/Cole Advanced Books \& Software Pacific Grove, California, USA.

CSIR (2005) National Land Cover Map of South Africa. CSIR, Pretoria, South Africa.

CRAWLEY MJ (1993) GLIM for Ecologists. Blackwell, Oxford.

DEPARTMENT OF WATER AFFAIRS AND FORESTRY (DWAF) (1999) Resource-Directed Measures for Protection of Water Resources. River Ecosystems, Volume 3. Version 1.0. Department of Water Affairs and Forestry, Pretoria, South Africa.

DEPARTMENT OF WATER AFFAIRS AND FORESTRY (DWAF) (2002a) Proposed 1st edn. National Water Resource Strategy. Ref. D3. Department of Water Affairs and Forestry, Pretoria, South Africa.

DEPARTMENT OF WATER AFFAIRS AND FORESTRY (DWAF) (2002b) Integrated Water Management Strategies, Guidelines, and Pilot Implementation in Three Water Management Areas, South Africa. Ref. J. No. 123/138-0154. Department of Water Affairs and Forestry, Pretoria, South Africa.

DEPARTMENT OF WATER AFFAIRS AND FORESTRY (DWAF) (2004) Internal Strategic Perspective: Crocodile (West) and Marico Water Management Area. Report No. P WMA 03/000/00/0303, Department of Water Affairs and Forestry, Pretoria, South Africa.

ESRI (1987) Environmental Systems Research Institute. Redlands, California, USA.

HIGGINS JV (2003) Maintaining the ebbs and the flows of the landscape. Conservation planning for freshwater ecosystems (Chapter 10). In: Groves, CR and contributors. Drafting a Conservation Blueprint: A Practitioner's Guide to Regional Planning for Biodiversity. Washington, DC, Island Press.

JENSEN DB, MS TORN and J HARTE (1993) In Our Own Hands: A Strategy for Conserving California's Biological Diversity. University of California Press, Berkeley.

KLEYNHANS CJ (1996) A qualitative procedure for the assessment of the habitat integrity status of the Luvuvhu River (Limpopo system, South Africa). J. Aquat.Ecosyst. Health 5 41-54

KLEYNHANS CJ (1999) The development of a fish index to assess the biological integrity of South African rivers. Water SA 25 (3) 265-278 (Online: http://www.wrc.org.za/publications watersa_july99.htm) 
KLEYNHANS CJ, C THIRION and J MOOLMAN J (2005) A Level I River Ecoregion Classification System for South Africa, Lesotho and Swaziland. Report No. N/0000/00/REQ0104. Resource Quality Services, Department of Water Affairs and Forestry, Pretoria, South Africa.

MATHSOFT INC (1999) S-PLUS Statistical Software. Mathsoft Inc., Cambridge, UK.

MORLEY SA and JR KARR (2002) Assessing and restoring the health of urban streams in Puget Sound basin. Conserv. Biol. 16 149814509.

MOYLE PB and JE WILLIAMS (1990) Biodiversity loss in the temperate zone: decline of the native fish fauna of California. Conserv. Biol. 4 275-284.

MOYLE PB and RA LEIDY (1992) Loss of biodiversity in aquatic ecosystems: evidence from fish faunas. Pages 128-169. In: PL Fiedler and SA Jain (editors). Conservation Biology: The Theory and Practice of Nature Conservation, Preservation, and Management. Chapman and Hall, New York.

NAIMAN RJ, H Decamps and M Pollock (1993) The role of riparian corridors in maintaining regional biodiversity. Ecol. Appl. 3209 212.

NEL J, G MAREE, D ROUX, J MOOLMAN, N KLEYNHANS, M SILBERBAUER and A. DRIVER (2004) South African National Spatial Biodiversity Assessment: Technical Report. Vol. 2: River Component. CSIR Report No. ENV-S-I-2004. CSIR, Stellenbosch, South Africa.

NORRIS RH and KR NORRIS (1995) The need for biological assessment of water quality. Austl. J. Ecol. 20 1-6.

NORRIS RH and MC THOMS (1999) What is river health? Freshwater Biol. 41 197-209.

OSBOREN LL and DA Kovacic (1993) Riparian vegetated buffer strips in water quality restoration and stream management. Freshwater Biol. 29 243-258.

QUIGLEY TM, RW HAYNES and WJ HANN (2001) Estimating ecological integrity in the interior Columbia River basin. Forest Ecol. Mgt. 153 161-178.
REVENGA C, J BRUNNER, N HENNINGER, K KASSEM and R PAYNE (2000) Pilot Analysis for Global Ecosystems. Freshwater Systems. Washington DC, USA: World Resources Institute.

RIVER HEALTH PROGRAMME (RHP) (2005) State-of-Rivers Report: Monitoring and Managing the Ecological State of Rivers in the Crocodile (West) and Marico Water Management Area. Department of Water Affairs and Forestry, Pretoria, South Africa.

ROTH NE, JD ALLAN, DL ERICKSON (1996) Landscape influences on stream biotic integrity assessed at multiple spatial scales. Landscape Ecol. 11 141- 156

ROUX D, F De MOOR, J CAMBRAY, and H BARBER-JAMES (2002) Use of landscape-level river signatures in conservation planning: A South African case study. Conserv. Ecol. 6 (2) 6. (Online: http:// www.cosecol.org/vol6/iss2/art6)

ROUX D, CJ KLEYNHANS, C THIRION, L HILL, JS ENGELBRECHT, AR DEACON and NP KEMPER (1999) Adaptive assessment and the management of riverine ecosystems: The Crocodile/Elands River case study. Water SA 25 (4) 501-512.

SPONSELLER RA, EF BENFIELD, HM VALETT (2001) Relationship between landuse, spatial scale and stream macroinvertebrate communities. Freshwater Biol. 46 1409-1424.

STOCKWELL DRB, and AT PETERSON (2002) Effects of sample size on accuracy of species distribution models. Ecol. Model. 148 1-13.

VANDERPOORTEN A, A SOTIAUX and P ENGELS (2005) A GIS survey for the conservation of bryophytes at the landscape scale. Biol. Conserv. 121 189- 194.

VITOUSEK PM, HA MOONEY, J LUBCHENCO and JM MELILLO (1997) Human domination of earth's ecosystems. Sci. 277 494-499.

WICKLUM D and RW DAVIES (1995) Ecosystem health and integrity. Can. J.Bot. 73 997-1000.

WORLD CONSERVATION UNION (IUCN) (2000) The 2000 IUCN Red List of Threatened Species. IUCN, Gland, Switzerland. Available from http://www.redlist.org/ 
Available on website http://www.wrc.org.za ISSN 0378-4738 = Water SA Vol. 33 No. 2 April 2007 ISSN 1816-7950 = Water SA (on-line) 